\title{
Effects of Replacing Fly Ash with Cutting Mud on the Performance of Ceramsite Aerated Concrete
}

\author{
Yonghe Yao*, Yanhong Wang, Zhiwu Liu, Fengpan Zhu
}

Jinhua Polytechnic, Jinhua 321007, China

Corresponding Author Email: 6298010@qq.com

https://doi.org/10.18280/acsm.430108

Received: 12 October 2018

Accepted: 25 January 2019

\section{Keywords:}

ceramsite aerated concrete (CAC), cutting mud, workability, compressive strength, dry density

\begin{abstract}
The cutting mud refers to the wastewater produced in the fabrication of ceramsite aerated concrete (CAC) blocks. To reduce the production and environmental impacts of these wastes, this paper puts forward a reuse plan that partially replaces the fly ash in CAC fabrication with the cutting mud. The dried powders in the mud of different concentrations were selected to replace an equivalent amount or a fewer amount of fly ash. The difference between the amount of dried powder and that of the fly ash being replaced was defined as the conversion coefficients. Then, the CACs fabricated under the equivalent replacement and under the converted replacement were compared in fluidity, compressive strength and dry density. The comparison shows that the CAC prepared when the cutting mud concentration is below $22 \%$ and the conversion coefficient is between 0.75 and 0.85 satisfies the production and quality requirements. Therefore, the wastewater produced in CAC fabrication can be treated effectively by replacing the fly ash with cutting mud. The replacement can reduce the harm and quantity of hazardous wastes, making them more recyclable.
\end{abstract}

\section{INTRODUCTION}

The ceramsite aerated concrete (CAC) block is a new selfinsulating wall material made from ceramsite, cement, fly ash and foaming agent [1]. These raw materials need to be prepared at a certain mix ratio, and go through mixing, pouring, curing and cutting, before forming CAC blocks. The CAC block has many advantages, such as lightweight, high strength, heat insulation, fire resistance, low shrinkage, and strong impermeability. It is a green energy-saving building material that is non-toxic, non-polluting, non-radioactive, and beneficial to the environment and human health [2-3].

Despite the said advantages, the fabrication of CAC blocks produces lots of cutting muds, which are often treated by natural sedimentation, plate and frame filter, or improper discharge. These treatments not only require long time and high cost, but also harm enterprise production and the surrounding ecology [4]. According to incomplete statistics, CAC block manufacturers on average produce over 40 ton of cutting muds on each cutting line. The traditional treatment approaches are too time-consuming, labor-intensive, and slow in water circulation to process the mud produced in the cutting operation. Against this backdrop, it is imperative to develop a method for CAC block manufacturers to effectively process cutting mud.

After visiting relevant manufacturers and reviewing the literature, the author discovered that the reuse of cutting mud in CAC block fabrication has neither been widely implemented by engineering technicians nor discussed indepth by scholars at home and abroad. Therefore, this paper attempts to disclose the effects of replacing fly ash with cutting mud over the CAC performance, and provide guidance on how to reduce the harm and quantity of cutting mud, making it more recyclable and applicable.

\section{EXPERIMENTAL MATERIALS EXPERIMENTAL PLAN}

AND

\subsection{Experimental materials}

(1) Ceramsite

The Grade 400 ceramsite was adopted for the fabrication of CA5.0B07 ceramsite CAC blocks. The technical parameters of the ceramsite are listed in Table 1 below.

Table 1. Main technical parameters of the ceramsite

\begin{tabular}{cccc}
\hline $\begin{array}{c}\text { Type of } \\
\text { ceramsite }\end{array}$ & $\begin{array}{c}\text { Bulk } \\
\text { density } \\
/\left(\mathrm{kg} \cdot \mathrm{m}^{-3}\right)\end{array}$ & $\begin{array}{c}\text { 1h water } \\
\text { absorptivity } \\
/ \%\end{array}$ & $\begin{array}{c}\text { Compressive } \\
\text { strength of concrete } \\
\text { cylinder } / \mathrm{MPa}\end{array}$ \\
\hline $\begin{array}{c}\text { Spherical } \\
\text { Grade 400 }\end{array}$ & 320 & 2.04 & 1.3 \\
\hline
\end{tabular}

(2) Cement

The cement in our research is Conch ordinary Portland cement 42.5. The technical parameters of the cement are given in Table 2 below.

Table 2. Main technical parameters of the cement

\begin{tabular}{ccccccc}
\hline $\begin{array}{c}\text { Mixture } \\
\text { yield } \\
1 \%\end{array}$ & $\begin{array}{c}\text { Loss } \\
\text { on } \\
\text { ignition } \\
1 \%\end{array}$ & $\begin{array}{c}\mathrm{SO}_{3} \\
1 \%\end{array}$ & $\begin{array}{c}\mathrm{MgO} \\
1 \%\end{array}$ & $\begin{array}{c}\text { Fineness } \\
1 \%\end{array}$ & $\begin{array}{c}\text { Initial } \\
\text { setting } \\
\text { time } \\
/ \mathrm{min}\end{array}$ & $\begin{array}{c}\text { Final } \\
\text { setting } \\
\text { time } \\
/ \mathrm{min}\end{array}$ \\
\hline 15 & 2.76 & 2.41 & 1.29 & 2.4 & 145 & 320 \\
\hline
\end{tabular}

\section{(3) Fly ash}

During the production of CAC blocks, the cement is partially replaced with fly ash to save cost and fill up the gaps [5], making the products denser. Here, the Grade II fly ash produced from Quzhou Juhua Thermal Power Plant is adopted 
for our research. The chemical composition of the fly ash is shown in Table 3 below.

\section{(4) Foaming agent}

This research uses the high-efficiency composite foaming agent produced by a catalyst plant in Shangyu, southeastern
China's Zhejiang Province. The main technical parameters of the foaming agent include the $\mathrm{pH}$ between 6 and 7, the stability of $40 \mathrm{~s}$, the bubbling times of 3.6 and the density of 1130 $\mathrm{kg} \cdot \mathrm{m}^{-3}$.

Table 3. Chemical composition of the fly ash

\begin{tabular}{ccccccccc}
\hline Chemical composition & $\mathrm{SiO}_{2}$ & $\mathrm{Al}_{2} \mathrm{O}_{3}$ & $\mathrm{Fe}_{2} \mathrm{O}_{3}$ & $\mathrm{CaO}$ & $\mathrm{MgO}$ & $\mathrm{K}_{2} \mathrm{O}$ & $\mathrm{Na}_{2} \mathrm{O}$ & Others \\
\hline Content $/ \%$ & 50.26 & 27.51 & 1.82 & 7.78 & 0.51 & 0.63 & 1.25 & 10.25 \\
\hline
\end{tabular}

Table 4. Physical parameters of the mud

\begin{tabular}{ccc}
\hline Specific gravity of mud $/\left(\mathrm{kg} \cdot \mathrm{m}^{-3}\right)$ & Mud concentration $/ \%$ & Powder content $/ \%$ \\
\hline 1090 & $16 \%$ & $15.7 \%$ \\
1110 & $18 \%$ & $17.73 \%$ \\
1126 & $20 \%$ & $19.80 \%$ \\
1140 & $22 \%$ & $21.95 \%$ \\
1153 & $24 \%$ & $24.05 \%$ \\
\hline
\end{tabular}

Table 5. Chemical composition of the dried powder

\begin{tabular}{ccccccccc}
\hline $\begin{array}{c}\text { Chemical } \\
\text { composition }\end{array}$ & $\mathrm{SiO}_{2}$ & $\mathrm{Al}_{2} \mathrm{O}_{3}$ & $\mathrm{Fe}_{2} \mathrm{O}_{3}$ & $\mathrm{CaO}$ & $\mathrm{MgO}$ & $\mathrm{K}_{2} \mathrm{O}$ & $\mathrm{Na}_{2} \mathrm{O}$ & Other \\
\hline Content/\% & 42.32 & 21.04 & 4.73 & 4.59 & 1.34 & 1.27 & 1.78 & 22.93 \\
\hline
\end{tabular}

\section{(5) Cutting mud}

The cutting mud was obtained from the wastewater, which is generated from the cutting of CAC raw materials, through sedimentation, slag removal, filtration, and stirring. The physical parameters of the mud are presented as Table 4 and the chemical composition of the dried powder is displayed in Table 5.

As shown in Table 4, the content of dried powder can be considered as the concentration of cutting mud, because of the high similarity between the two figures. Previous test results show that $85 \% \sim 95 \%$ of the water in the mud are in free form, and the remaining $5 \% \sim 15 \%$ are adsorbed [5]. Comparing Table 5 with Table 3, it is clear that the dried powder of cutting mud have basically the same chemical composition as the fly ash, except a $14 \% \sim 15 \%$ reduction in the content of active matters like $\mathrm{SiO}_{2}, \mathrm{Al}_{2} \mathrm{O}_{3}$ and $\mathrm{CaO}$. Since fly ash mainly acts as fillers in the CAC, it is theoretically feasible to replace the fly ash with the dried powder of cutting mud.

\subsection{Experimental plan}

The mix ratio of CA5.0B07 ceramsite CAC blocks was designed for the raw materials according to the mix ratio design method in the Technical Specification for Lightweight Aggregate Concrete (JGJ51-2002) and the requirements in the Ceramsite Aerated Concrete Block (JG/T504-2016). The mix ratio was taken as the benchmark mix ratio (Table $6 \mathrm{a}$ and Table 6b).

Table 6a. Benchmark mix ratio

\begin{tabular}{cccccc}
\hline \multicolumn{6}{c}{ Dosage of raw materials $/\left(\mathrm{kg} \cdot \mathrm{m}^{-3}\right)$} \\
\hline Ceramsite & Cement & $\begin{array}{c}\text { Fly } \\
\text { ash }\end{array}$ & Water & $\begin{array}{c}\text { Foaming } \\
\text { agent }\end{array}$ & $\begin{array}{c}\text { Water- } \\
\text { binder } \\
\text { ratio }\end{array}$ \\
275 & 235 & 170 & 182 & 0.4 & 0.45 \\
\hline
\end{tabular}

Table 6b. Technical parameters

\begin{tabular}{|c|c|c|c|c|}
\hline \multirow{2}{*}{$\begin{array}{l}\text { Slump } \\
/ \mathrm{mm}\end{array}$} & \multicolumn{2}{|c|}{$\begin{array}{c}\text { Compressive strength } \\
/ \mathrm{MPa}\end{array}$} & \multicolumn{2}{|c|}{ Dry density $/\left(\mathrm{kg} \cdot \mathrm{m}^{-3}\right)$} \\
\hline & $\begin{array}{l}\text { Measured } \\
\text { value }\end{array}$ & $\begin{array}{l}\text { Standard } \\
\text { value }\end{array}$ & $\begin{array}{l}\text { Measured } \\
\text { value }\end{array}$ & $\begin{array}{l}\text { Standard } \\
\text { value }\end{array}$ \\
\hline $\begin{array}{l}120- \\
150\end{array}$ & 6.16 & $\geq 5.0$ & 708 & $\leq 750$ \\
\hline
\end{tabular}

In light of the benchmark mix ratio, the dried powder of the cutting mud with the contents of $16 \%, 18 \%, 20 \%, 22 \%$ and $24 \%$ were selected to replace an equivalent amount of fly ash, at the water-binder ratio of 0.45 . The mix ratios in these experiments are listed in Table 7

Table 7. Mix ratios in equivalent replacement experiments

\begin{tabular}{cccccc}
\hline $\begin{array}{c}\text { Mud } \\
\text { concentrat } \\
\text { ion /\% }\end{array}$ & \multicolumn{4}{c}{ Dosage of raw materials in the CAC $/\left(\mathrm{kg} \cdot \mathrm{m}^{-3}\right)$} \\
Ceramsite & Cement & $\begin{array}{c}\text { Fly } \\
\text { ash }\end{array}$ & $\begin{array}{c}\text { Cemen } \\
\mathrm{t}\end{array}$ & $\begin{array}{c}\text { Foamin } \\
\text { g agent }\end{array}$ \\
\hline 16 & 275 & 235 & 135 & 217 & 0.4 \\
18 & 275 & 235 & 130 & 222 & 0.4 \\
20 & 275 & 235 & 124 & 228 & 0.4 \\
22 & 275 & 235 & 119 & 234 & 0.4 \\
24 & 275 & 235 & 112 & 240 & 0.4 \\
\hline
\end{tabular}

Considering the loss of active matters and free water in the dried powder of cutting mud, the mud concentration of $20 \%$ was selected, and the dried powder of the mud was used to replace fly ash. The amount of fly ash being replaced is 0.55 , 
$0.65,0.75,0.85$ and 0.9 of that of the dried powder, respectively. These ratios are known as the conversion coefficients between dried powder and fly ash. The mix ratios in these experiments are listed in Table 8.

Table 8. Mix ratios in converted replacement experiments

\begin{tabular}{ccccccc}
\hline \multirow{2}{*}{ Conversion coefficient } & \multicolumn{5}{c}{ Dosage of raw materials in the CAC $/\left(\mathrm{kg} \cdot \mathrm{m}^{-3}\right)$} \\
& Ceramsite & Cement & Fly ash & Mud & Foaming agent & Water-binder ratio \\
\hline 0.55 & 275 & 235 & 144 & 228 & 0.4 & 0.43 \\
0.65 & 275 & 235 & 140 & 228 & 0.4 & 0.43 \\
0.75 & 275 & 235 & 135 & 228 & 0.4 & 0.44 \\
0.85 & 275 & 235 & 131 & 228 & 0.4 & 0.44 \\
0.95 & 275 & 235 & 127 & 228 & 0.4 & 0.45 \\
\hline
\end{tabular}

The raw materials were weighed accurately by the mix ratios. Firstly, the cement was mixed with the fly ash. Then, the mud and foaming agent were blended into the mixture. After that, the ceramsite was added, and the mixture was stirred well for workability test. Next, the mixture was poured into a $150 \mathrm{~mm} \times 150 \mathrm{~mm} \times 550 \mathrm{~mm}$ test mold, and then subjected to vibration and curing. After mold removal, the solidified concrete was cut into $100 \mathrm{~mm} \times 100 \mathrm{~mm} \times 100 \mathrm{~mm}$ blocks for compressive strength and dry density tests.

\section{EXPERIMENTAL RESULTS AND DISCUSSION}

\subsection{Effect of mud concentration on CAC fluidity}

The CAC mixtures were prepared by the mix ratios in Tables 7 and 8, respectively. The experiments on these mixtures show that the CAC achieved required workability, cohesiveness and water-holding capacity. The slump of fluidity in equivalent and converted replacement experiments are presented in Figures 1 and 2, respectively.

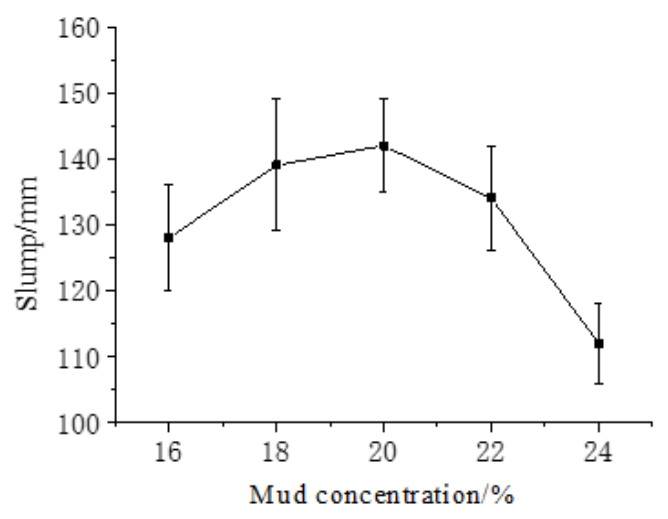

Figure 1. Effect of equivalent replacement on fluidity

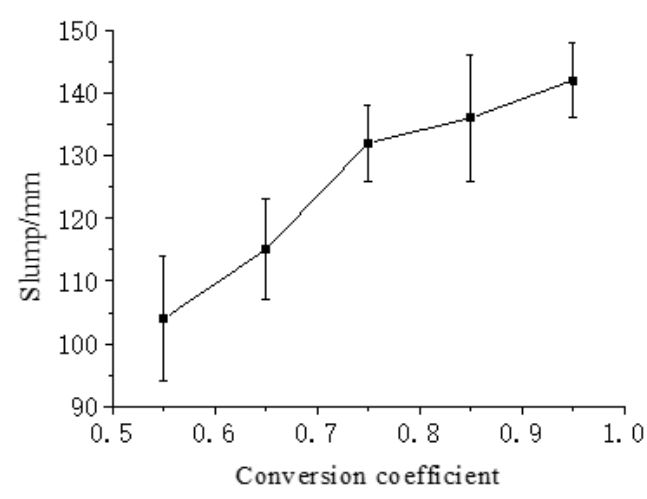

Figure 2. Effect of converted replacement on fluidity
It can be seen from Figure 1 that the fluidity of the CAC mixture increased before decreased with the growth in mud concentration. At the beginning, the slurry became thicker as more mud was added. In this case, the bubbles produced by the foaming agent could exist stably [6], pushing up the fluidity. When the mud concentration surpassed $20 \%$, however, the fluidity was reduced due to the decline in the percentage of free water. As shown in Figure 2, the CAC mixture was increasingly fluid with the growth in the conversion coefficient. Initially, the dosages of fly ash and dried powder were reduced with increase of the conversion coefficient, making the slurry thinner and the water-binder ratio greater. After the conversion coefficient exceeded 0.75 , the fluidity still stayed above the slump required for the benchmark mix ratio, and no segregation or bleeding was observed.

\subsection{Effect of mud concentration on the compressive strength of the CACs of different ages}

The CAC blocks were prepared by the mix ratios in Tables 7 and 8, respectively, and subjected to compressive strength tests. The compressive strengths in equivalent and converted replacement experiments are displayed in Figures 3 and 4, respectively.

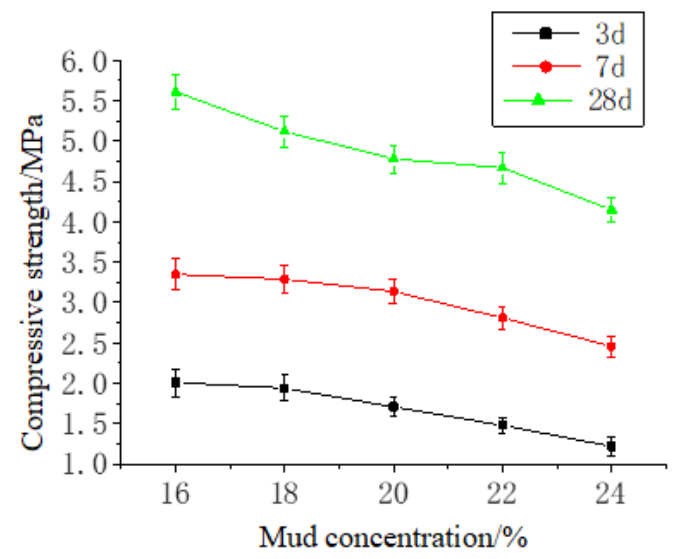

Figure 3. Effect of equivalent replacement on compressive strength

As shown in Figure 3, the compressive strength of the CAC exhibited a decline with the rising concentration of the mud. In the early phase, $3 \mathrm{~d}$ and $7 \mathrm{~d}$ CACs were weaker than that of the benchmark mix ratio, while the $28 \mathrm{~d}$ CAC was close to the latter in compressive strength. The compressive strength plunged deeply when the mud concentration surpassed $22 \%$. The huge loss of strength in the early phase is attributable to the relatively few active matters in the dried powder, which replaced more and more fly ash with the growth in mud 
content [7-8]. In the later phase, the compressive strength rose again, for the adsorbed water released from the mud promoted cement hydration. It can be seen from Figure 4 that the compressive strength of the CAC increased with the reduction in the conversion coefficient. This is because the mud dosage was gradually falling, although the growing dosage of fly ash made up for the loss of active matters in the dried powder. Therefore, it is an economic and rational way to fabricate CAC blocks whose compressive strength meets the requirement of the Ceramsite Aerated Concrete Block (JG/T504-2016) by setting the conversion coefficient in $0.70 \sim 0.85$.

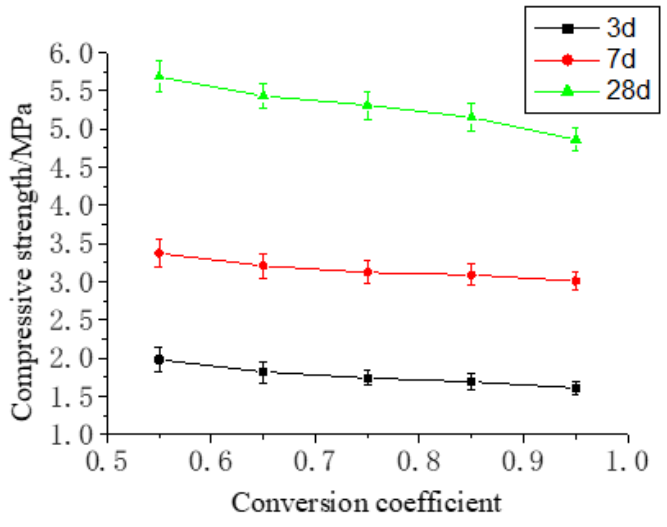

Figure 4. Effect of converted replacement on compressive strength

\subsection{Effect of mud concentration on the dry density of the CAC}

The CAC blocks were prepared by the mix ratios in Tables 7 and 8 , respectively, and subjected to dry density tests. The results of equivalent and converted replacement experiments are shown in Figures 5 and 6, respectively.

It can be seen from Figure 5 that, with the increase in mud concentration, the CAC dry density approximated the dry density of the benchmark mix ratio through an unobvious growth, and fell within the allowable range. This trend took place because the total amount of the raw materials did not change; almost all water in the mud participated in the cement hydration, while only a few was volatized in the curing process [9-10]. Figure 6 shows that the CAC dry density had an obvious negative correlation with the conversion coefficient, because the dry density fell in the allowable range when the conversion coefficient was above 0.70 , after the dry ash was added to supplement the lack of active matters in dried powder.

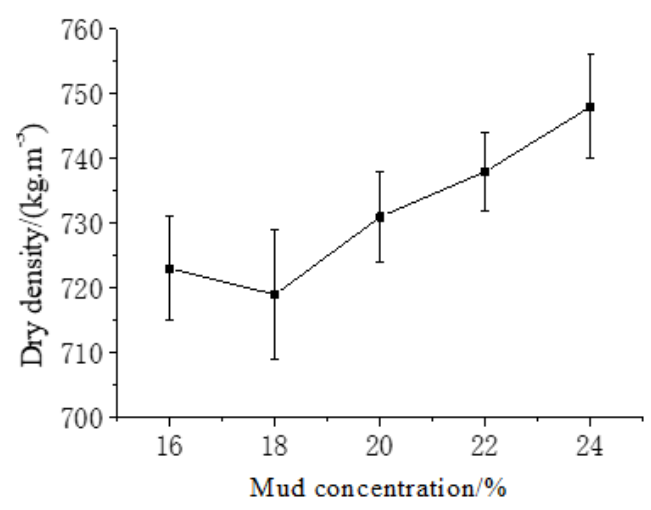

Figure 5. Effect of equivalent replacement on dry density

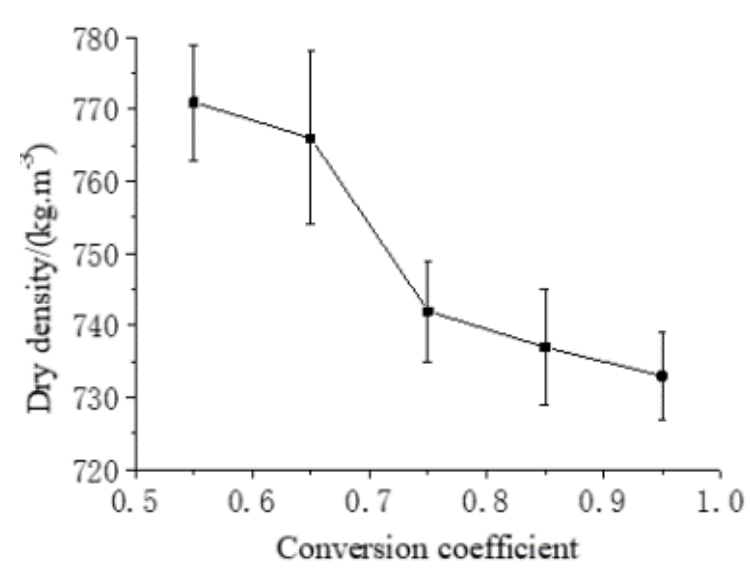

Figure 6. Effect of converted replacement on compressive strength

\section{CONCLUSIONS}

Focusing on CA5.0B07 ceramist CAC blocks, this paper explores the effects of partial replacement of fly ash with cutting mud over the CAC performance under constant waterbinder ratio and actual mix ratios. The experimental results show that the CAC prepared when the cutting mud concentration is below $22 \%$ and the conversion coefficient is between 0.75 and 0.85 has similar fluidity, compressive strength and dry density with that prepared without adding any mud. Under these technical parameters, the mud recyclability is relatively high, and the requirements in the ceramist Aerated Concrete Block (JG/T504-2016) can be satisfied. Thus, it is a feasible and rational technical and economic approach to replace the fly ash in the fabrication of CAC blocks with cutting mud, which sheds new light on the thorny issue of cutting mud treatment. This approach turns bane into a boon and waste into treasure, reduces the harm and quantity of hazardous wastes, making them more recyclable, and effectively prevents the secondary pollution of mud to the environment

\section{REFERENCES}

[1] Nie L, Zhang Y. (2011). Study on the application of lightweight aggregate ceramsite concrete in building. Applied Mechanics and Materials 71-78: 573-576. https://doi.org/10.4028/www.scientific.net/AMM.7178.573

[2] Jiang YB, Wang XR. (2010). Research on thermal and structural performances of shale ceramsite concrete. advanced materials research 168-170: 885-888. https://doi.org/10.4028/www.scientific.net/amr.168170.885

[3] Zheng XH, Zhang BS, Jie Y. (2006). Microstructure and mechanical properties of shale ceramsite concrete. Key Engineering Materials 302-303: 371-375. https://doi.org/10.4028/www.scientific.net/kem.302303.371

[4] Liu JZ. (2011). Study on performance of concrete made from sewage sludge ceramsite. The Open Materials Science Journal 5(1): 123-129. https://doi.org/10.2174/1874088x01105010123

[5] Sajedi F, Shafigh P. (2012). High-strength lightweight concrete using LECA, silica fume and limestone. 
Arabian Journal for Science and Engineering 37(7): 1885-1893. https://doi.org/10.1007/s13369-012-0285-3

[6] Yang WJ, Jiang PX, Wang Y. (2011). A study on ceramsite pre-wetted time to work on the performance of ceramsite aggregate concrete. Advanced Materials Research 393-395:

11-14. https://doi.org/10.4028/www.scientific.net/amr

[7] Garcia NM, Zapata LE, Suárez OM. (2015). Effect of fly ash and nanosilica on compressive strength of concrete at early age. Advances in Appiled Ceramics 114(2): 99 106. https://doi.org/10.1179/1743676114Y.0000000200

[8] Long GC, Yang JE, Xie YJ. (2016). The mechanical characteristics of steam-cured high strength concrete incorporating with lightweight aggregate. Construction and Building

Materials.

https://doi.org/10.1016/j.conbuildmat.2016.12.171

[9] Wu FZ, Wang WH. (2010). Additives on the Performance of ceramsite concrete. Advanced Materials Research 168-170: 2074-2077. https://doi.org/10.4028/www.scientific.net/amr.168 170.2074

[10] Malaiškienė J, Vaičienė M, Žurauskienė R. (2011). Effectiveness of technogenic waste usage in products of building ceramics and expanded clay concrete. Construction and Building Materials 25(10): 3869-3877. https://doi.org/10.1016/j.conbuildmat.2011.04.008 